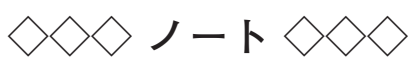

\title{
生おからを用いた加工食品の品質予測に基づく 焼成条件の検討
}

\author{
柴田 (石渡) 奈緒美 ${ }^{1, \dagger}$ ，渡邊桃子 ${ }^{1}$, 福岡美香 ${ }^{2}$, 酒井 昇 $^{2}$ \\ ${ }^{1}$ 岐皁大学, ${ }^{2}$ 東京海洋大学
}

\section{Examination of the Heating Condition Based on the Quality Prediction of the Processed Food Product Using Raw Okara}

\author{
Naomi Shibata-ISHIWATARI ${ }^{1, \dagger}$, Momoko WATANABE $^{1}$, Mika FUKUOKA $^{2}$, Noboru SAKAI $^{2}$ \\ ${ }^{1}$ Gifu University, 1-1 Yanagito, Gifu city, Gifu 501-1193, Japan \\ ${ }^{2}$ Tokyo University of Marine Science and Technology, 4-5-7 Konan, Minato-ku, Tokyo 108-8477, Japan
}

\begin{abstract}
This study focused on the processed food products, using raw okara (a food product developed to mitigate problems associated with mass disposal of soy waste). To examine the heating condition effectively, we simulated food qualities during heating. Color change was treated as a first-order reaction, and kinetic parameters $\left(E_{\mathrm{a}}=61.6 \mathrm{~kJ} / \mathrm{mol}, \quad Z=4.93 \times 10^{5} 1 / \mathrm{s}\right)$ were calculated by Golden section method. Moisture content was calculated via mass transfer analysis, based on Fick's laws of diffusion. Our simulation predicted values for color, moisture content, water activity, and texture that were in good agreement with experimental values. We determined that, to achieve an equivalent to a commercial product, it was suggested that about $1 / 2$ could shorten heating time by changing surface temperature from $80^{\circ} \mathrm{C}$ to $120^{\circ} \mathrm{C}$. Thus, this simulation technique can contribute to the shortening of heating times for processed food products.
\end{abstract}

Keywords: simulation technique, quality, mass transfer analysis, raw okara

1. 緒言

豆腐は日本人の食卓に欠かすことのできない食材の 1 つであるが，豆腐の製造過程に副産物として排出さ れる扔からは，豊富な栄養価と機能性を有しているに も関わらず大量に廃棄さ扎ている。午のため，打から の有効利用を目的とし主食であるパン類 [1-4], 麺類 [4]，コロッケなどの惣菜類 [5]，ケーキ，クッキーな どの菓子類 $[5,6]$ と多岐に渡る加工食品の開発が検討さ れている。しかしこれらの食品に使用されたおからは， 加熱機器を用いて乾燥させた乾燥抢からや，加熱ぺー スト化した打からなど一次加工が施されているため, 実際に商品化を行うには一次加工を施すための機械の 新規導入や，加工時にエネルギーが必要となる。この ような背景から柴田ら [7] は，一次加工を施していない 打から（以降，生打から）を焼成前の生地重量に対し

(受付 2016 年 12 月 16 日，受理 2017 年 2 月 22 日

1 ₹501-1193 岐皁県岐皁市柳戸1-1

2 于 108-8477 東京都港区港南4-5-7

$\dagger$ FAX: 058-293-2305, E-mail: naomi_i@gifu-u.ac.jp
て $70 \%$ 使用したシリアルに類似した加工食品の開発を

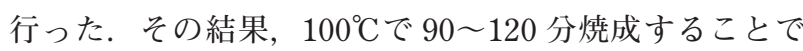
試料の色彩值，含水率，水分活性が市販品のブランフ レークの定量值と同等な值を示すことを明らかにした。 しかし，この食品を加工するのに要した焼成時間は 90 〜120 分と長時間であり，実際に製造するには現実的な 焼成条件ではないと考えられる。爷こで本研究は試料 の品質予測を可能とすることで，効率的に品質と保存 性を担保した製品の焼成条件を探索することを目的と した。また品質予測に関する既存の報告は音肉食品の 硬さ [8], 呈味成分 [9], 安全評価 [10,11], 重量損失 [12,13]，魚やパン，クラッカー色彩 [14-22] など多岐 に渡るが，これらの報告は破断の応力，色彩変化など 1 つの品質のみを予測するための数学モデルの構築やパ ラメータの取得が行われている。しかし，一般的に食 品の品質は見た目，食感そして安全性と複数の項目を 横断して打り，総合的に判断されていることから，食 品産業で商品化や製造条件を検討する際は一度に複数 の品質を同時に予測する必要があると考えられる。そ こで本研究は見た目の指標として色彩值，含水率，保 
存性の指標として水分活性，食感の指標として破断応 力の 4 項目について予測計算を試みた。

\section{2. 実験}

\section{1 試料作製および焼成方法}

材料には（株）ライクスタカギから提供された岐皁 県産生打から, 小麦粉 (薄力小麦粉, (株) シージーシー ジャパン)，砂糖（上白糖，伊藤忠製糖（株））打よび 卵（森のたまご，イセ食品（株））を用いた。実験に使 用した材料の乾物基準含水率は，生打から $2.51 \pm 0.01$ $\left(\mathrm{g}_{\text {-water }} / \mathrm{g}_{\text {-solid }}\right)$, 小麦 $0.19 \pm 0.02\left(\mathrm{~g}_{\text {-water }} / \mathrm{g}_{\text {-solid }}\right)$, 卵 2.98 $\pm 0.04 \quad\left(\mathrm{~g}_{\text {-water }} / \mathrm{g}_{\text {-solid }}\right)$ であった。柴田ら [7] の作製方 法に従い生抢から $70 \%$, 小麦粉 $12 \%$, 卵 $10 \%$, 砂糖 8\% の重量割合で配合し，一度に作製した生地の重量は 428 $\mathrm{g}$ (生おから $300 \mathrm{~g}$ ) とした. 平面ビーターを設置したキッ チンエイドミキサー (KSM150,（株）エフ・エム・アイ) に全ての材料を投入し，速度 4 で 5 分間摚找後，直径 $20 \mathrm{~mm}$, 厚さ $1.50 \pm 0.27 \mathrm{~mm}$ の円筒形試料を作製した。 その後，クッキングシートを敷いたオーブン典の上に 成型した試料 90 枚を置き, 家庭用オーブン (MRO-NS7, （株）日立製作所）を用いて焼成した。オーブンの設定 温度は $100^{\circ} \mathrm{C} ， 120^{\circ} \mathrm{C}$ および $150^{\circ} \mathrm{C}$ とた。

\section{2 品質定量}

\subsection{1 温度履歴}

温度測定には被覆型熱電対（K型， $\phi 0.3 \mathrm{~mm}$ ）を使 用し，試料表面と試料表面から高さ $15 \mathrm{~mm}$ の環境温度 の 2 箇所を測定した。試料表面を測定する際は，熱電 対の先端から $50 \mathrm{~mm}$ 程度生地に密着させ，焼成中に熱 電対が生地から外れないよう留意した。
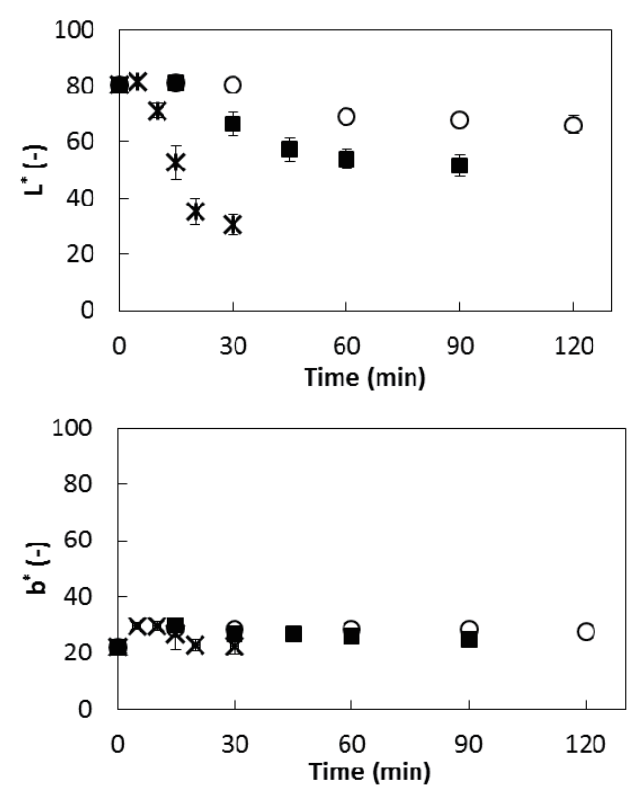

\subsection{2 色彩値}

簡易型分光色差計 (NF333，日本電色工業（株））を 使用し，試料表面の $\mathrm{L}^{*} ， \mathrm{a}^{*}$ 打よび $\mathrm{b}^{*}$ 值を測定した。ま た本研究の焼成前の試料の厚さは $1.50 \pm 0.27 \mathrm{~mm}$ と薄 いことから，光の透過に伴う色彩值への影響を抑制す るため, 測定時は白色の紙の上に試料を載せて測定を 行った.

\subsection{3 含水率および水分活性}

焼成後の試料を $105^{\circ} \mathrm{C}$ に設定した恒温槽 (DA-600FA, アズワン (株)）を用いて 24 時間乾燥させ，乾燥前後 の試料重量から乾物基準含水率を算出した。また水分 活性計 (Pawkit，アイネクス (株)) を使用し，水分活 性を測定した。

\subsection{4 破断応力}

レオメーター（RE-3305S，（株）山電）を用いて試 料の破断強度を測定し，プランジャーと試料の接触面 積（刃幅 $35 \mathrm{~mm} \times$ 試料直径 $20 \mathrm{~mm}$ ） から破断に要する 破断応力を算出した.

\section{3. 結果および考察}

\section{1 温度および色彩値}

全ての設定温度に打いて，オーブン庫内の環境温度は 温度を一定に保つために設定温度の前後 $10^{\circ} \mathrm{C}$ の温度帯で 上昇下降を繰り返した。表面温度は設定温度 $120^{\circ} \mathrm{C}$ と $150^{\circ} \mathrm{C}$ は環境温度の上昇下降に対応しながら最大焼成時 間まで上昇を続けたが，設定温度 $100^{\circ} \mathrm{C}$ の表面温度は焼 成開始から約 15 分後に $80^{\circ} \mathrm{C}$ 到達以降，環境温度に依存 して上昇下降を繰り返すのみだった。焼成時間の経過に 伴う色彩值を測定した結果を Fig.1に示す．材料である 生扔から，小麦粉，砂糖には糖類とアミノ酸が存在する

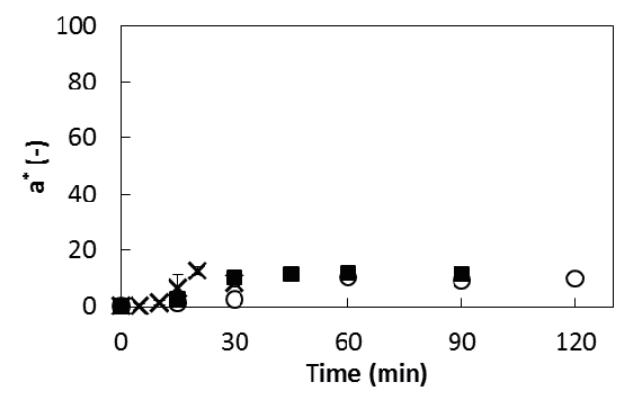

$$
0100^{\circ} \mathrm{C}
$$

- $120^{\circ} \mathrm{C}$

$\times 150^{\circ} \mathrm{C}$

Fig.1 Measured values of surface color changes during heating. The temperature shows the setting temperature of the oven. The values are expressed as the mean \pm S.D. $(n=25)$ 


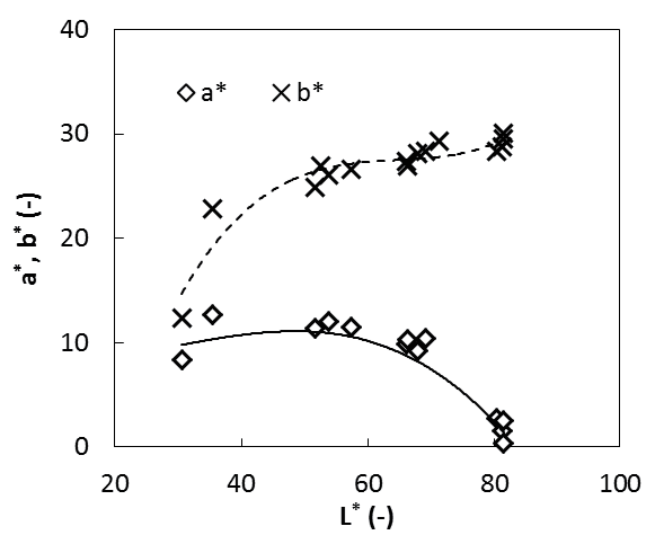

Fig.2 The relationships between $\mathrm{L}^{*}-\mathrm{a}^{*}$ and $\mathrm{L}^{*}-\mathrm{b}^{*}$. Solid line and dotted line represent the correlation of the calculated values.

ため，焼成に伴いメイラード反応が生じ，色彩が変化し た. Fig.1より， $\mathrm{L}^{*} \mathrm{a}^{*} \mathrm{~b}^{*}$ の中で $\mathrm{L}^{*}$ が最も数值の変化が大 きく， $\mathrm{L}^{*}$ は全ての設定温度に打いて焼成開始直後はわず かに上昇するが，その後は緩やかに減少する傾向が見て 取れる。 そこで各設定温度で $\mathrm{L}^{*}$ が最大值を示した焼成 時間（設定温度 $100^{\circ} \mathrm{C} \cdot 120^{\circ} \mathrm{C} 15$ 分, 設定温度 $150^{\circ} \mathrm{C} 5$ 分） に打ける表面温度を確認したところ, 設定温度 $100^{\circ} \mathrm{C}$ は $78.7^{\circ} \mathrm{C}, 120^{\circ} \mathrm{C}$ は $79.1^{\circ} \mathrm{C}, 150^{\circ} \mathrm{C}$ は $77.9^{\circ} \mathrm{C}$ とほぼ等しいこ とから，L" は表面温度が約 $80^{\circ} \mathrm{C}$ に到達後，緩やかに減 少することが示唆された。また $\mathrm{L}^{*}$ が最大值を示した試 料を白色と黒色の紙の上に載せ測定した色彩值は等し かったことから，光の透過に伴う色彩值への影響はない と判断した。焼成に伴う色彩值を定量した既存の報告に 打いて [15-19]， L*に対して $\mathrm{a}^{*} と \mathrm{~b}^{*}$ は相関があると述 べられている。本研究の実験結果からも， $\mathrm{a}^{*}$ は $\mathrm{L}^{*}$ が上 昇している焼成開始直後はわずかに増加し, $\mathrm{b}^{*}$ は $\mathrm{L}^{*}$ の 低下とともに減少する傾向がみられたことから $\mathrm{a}^{*}$ 打よび

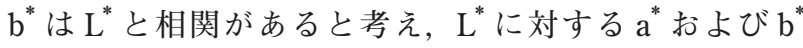
のグラフを作成し (Fig.2)， $\mathrm{L}^{*}$ から $\mathrm{a}^{*}$ と $\mathrm{b}^{*}$ を算出する 式を導出した。

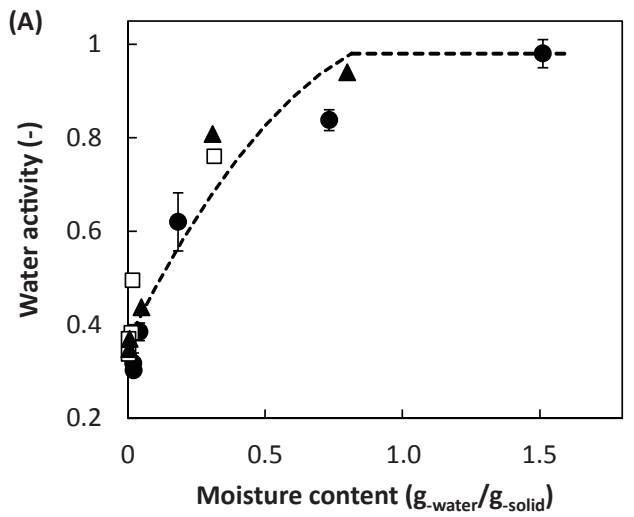

$$
\begin{aligned}
a^{*}=-9.34 & \times 10^{-5} L^{* 3}+7.77 \times 10^{-3} L^{* 2} \\
& -9.55 \times 10^{-2} L^{*}+8.1 \quad\left(R^{2}=0.82\right) \\
b^{*}=3.01 \times & 10^{-4} L^{* 3}-5.83 \times 10^{-2} L^{* 2} \\
& +3.79 L^{*}-5.54 \times 10 \quad\left(R^{2}=0.90\right)
\end{aligned}
$$

ただし， L 值が最も高い焼成前の值は $81.4 \pm 0.79$, 最も 数值が低下した設定温度 $150^{\circ} \mathrm{C} ， 30$ 分焼成した $\mathrm{L}^{*}$ 值は $30.6 \pm 3.49$ であることから，(1）式打よび（2）式は 30.6 $\leq L^{*} \leq 81.4$ の範囲において適応可能であると判断した.

\section{2 含水率, 水分活性および破断応力}

焼成前の生地の含水率は $1.50 \pm 0.01\left(\mathrm{~g}_{\text {-water }} / \mathrm{g}_{\text {-solid }}\right)$, 水分活性は $0.98 \pm 0.03(-)$ であった。含水率と水分 活性は焼成時間の経過に伴い数値が低下し，設定温度 が高いほど減少速度は速くなった。実測した水分活性 も含水率と同様な減少傾向がみられたことから，含水 率と水分活性は相関があると考え，含水率に応じた水 分活性の近似式を導出した（Fig.3 (A)).

$$
A_{w}=-0.52 M^{2}+1.18 M+0.37
$$

ここで $A_{\mathrm{w}}$ は水分活性 $(-), M$ は含水率 $\left(\mathrm{g}_{\text {-water }} / \mathrm{g}_{\text {-solid }}\right)$ を表す。ところで(3) 式は上に凸の二次関数であるため, 含水率 1.13 の時に最大值 1.03 を示すが，水分活性の最 大值は 1.00 であり，理論的に適していない，そこで（3) 式から，実験で得られた水分活性の最大值 0.98 に到達 する含水率 0.815 を算出し, 含水率 0.815 より高い範囲 では水分活性は常に 0.98 であるとみなした。また試料 を十分に焼成し水分量が低下した含水率 0.01 に打いて も，（3）式から予測した水分活性 0.37 は実測値（0.34 $\pm 0.02 ）$ と大きな差はないことから，（3）式は $0<M$ $\leq 1.5$ の範囲に扔いて適応可能であると判断した.

破断応力は全ての設定温度に打いて焼成時間の経過 に伴い值は大きくなり，かつ，設定温度が高くなると 数值の上昇が著しいことが明らかとなった。また各設

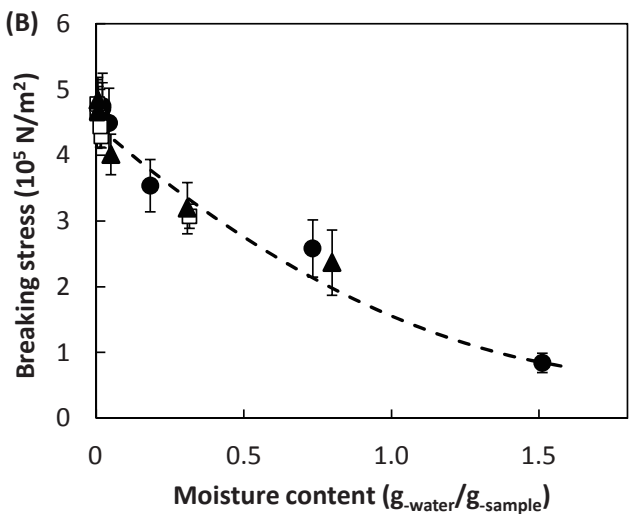

Fig.3 The relationship between moisture content - water activity (A), and moisture content - breaking stress (B). Solid lines represent the correlation of the calculated values. The temperature shows the setting temperature of the oven $\left(100^{\circ} \mathrm{C}, \square: 120^{\circ} \mathrm{C}, \boldsymbol{\Delta}: 150^{\circ} \mathrm{C}\right)$. The values are expressed as the mean \pm S.D. $(n=6)$ 
定温度の平衡值に到達した時間は，含水率が平衡值に 到達する時間と打打よそ等しかったことから，破断応 力と含水率に相関があると考光，含水率に対する破断 応力を示した $($ Fig.3 (B)) . Fig.3（B）より含水率が 低下するほど破断応力は増加することがみて取れる. そこで, 含水率に応じた破断応力の近似式を導出した。

$$
H=9.95 \times 10^{4} M^{2}-3.89 \times 10^{5} M+4.45 \times 10^{5} \quad\left(R^{2}=0.94\right) \quad(4)
$$

ここで $H$ は破断応力 $\left(\mathrm{N} / \mathrm{m}^{2}\right)$ を表す，(4) 式より推算 した初期含水率 1.50 に打ける破断応力は $8.53 \times 10^{4} \mathrm{~N} /$ $\mathrm{m}^{2}$, 試料を十分に焼成し水分量が低下した含水率 0.01 に打ける破断応力は $4.42 \times 10^{5} \mathrm{~N} / \mathrm{m}^{2}$ と，それ乤机実測 值 $\left(8.43 \times 10^{4} \pm 1.47 \times 10^{4} \mathrm{~N} / \mathrm{m}^{2}, 4.43 \times 10^{5} \pm 3.10 \times 10^{4}\right.$ $\left.\mathrm{N} / \mathrm{m}^{2}\right)$ と一致していることから，(4) 式は $0<M \leq 1.50$ の範囲に打いて適応可能であると判断した。

このように含水率に応じて，保存性を左右する水分 活性と食感の指標となる破断応力を推算することが可 能となった。

\section{3 理論}

色彩值 $\mathrm{a}^{*}$ と $\mathrm{b}^{*}$ は $\mathrm{L}^{*}$ から, 水分活性と破断応力は含 水率から推算することが可能となった。 そこで次に, 基準となる $\mathrm{L}^{*}$ と含水率の焼成時間の経過に伴う変化の 予測を試みた。

\subsection{1 色彩值}

実験結果から試料表面温度が約 $80^{\circ} \mathrm{C}$ に到達した際, $\mathrm{L}^{*}$ は最大值を示し，その後，緩やかに $\mathrm{L}^{*}$ が減少する際 に呈色が進行することが示唆された。そこで本研究に 打ける呈色反応は, 試料表面温度 $80^{\circ} \mathrm{C}$ 以上に打いて, 試料表面の物質 $\mathrm{A}$ が加熱によって呈色した物質 $\mathrm{P}$ に変 化したことに起因すると仮定した場合，（6）式で表す ことができる，さらに，物質 $\mathrm{A}$ の濃度 C の変化が無次 元化した $\mathrm{L}^{*}$ の変化と等しいと仮定した場合，（7）式が 成り立つ.

$$
\begin{gathered}
\mathrm{A} \rightarrow \mathrm{P} \\
\frac{d C_{P}}{d t}=-\frac{d C_{A}}{d t}=-k C_{A} \\
X=\frac{\left(C_{P f}-C_{P}\right)}{\left(C_{P f}-C_{i}\right)}=\frac{\left(L_{f}^{*}-L^{*}\right)}{\left(L_{f}^{*}-L_{i}^{*}\right)}
\end{gathered}
$$

ここで, $C$ は呈色変化する物質の濃度 $(\mathrm{mol} / \mathrm{g}), k$ は呈 色反応の速度定数 $(1 / \mathrm{s}), t$ は時間 $(\mathrm{s}), X$ は無次元化 した $\mathrm{L}^{*}$ の割合 $(-), \mathrm{L}_{\mathrm{i}}^{*}$ は初期 $\mathrm{L}^{*}, \mathrm{~L}_{\mathrm{f}}^{*}$ は最終 $\mathrm{L}^{*}$ を示す. 時刻 $t$ に打ける無次元化した $\mathrm{L}^{*}$ の割合 $X$ は（8）式で 求めることができ, 色彩值変化の速度定数 $k$ の温度依 存性は（9）式に示すアレニウスの式に従うとした.

$$
\begin{gathered}
\frac{d X}{d t}=-k X \\
k=Z \exp \left(-\frac{E_{\mathrm{a}}}{R T}\right)
\end{gathered}
$$

ここで, $Z$ は色彩值変化の頻度因子 $(1 / \mathrm{s}), T$ は温度 $(\mathrm{K})$, $E_{\mathrm{a}}$ は色彩値変化の活性化エネルギー $(\mathrm{kJ} / \mathrm{mol}), R$ は気 体定数 $(\mathrm{J} /(\mathrm{mol} \cdot \mathrm{K}))$ を示す。また，(8) 式と（9) 式は（10）式で表される.

$$
\frac{d X}{d t}=-Z \exp \left(-\frac{E_{\mathrm{a}}}{R T}\right) X
$$

\subsection{2 含水率}

フィックの法則に基づく水分移動の基礎式は（11） 式で表される.

$$
\frac{\partial C_{\mathrm{m}}}{\partial t}=-\operatorname{div}\left(J_{\mathrm{m}}\right)
$$

ここで, $J_{\mathrm{m}}$ は水分移動流束 $\left(\mathrm{kg} / \mathrm{m}^{2} \mathrm{~s}\right)$ を示し, 式で表される。

$$
J_{\mathrm{m}}=-D \cdot \operatorname{grad}\left(C_{\mathrm{m}}\right)
$$

ここで, $D$ は拡散係数 $\left(\mathrm{m}^{2} / \mathrm{s}\right)$ を表し, 拡散係数の温 度依存性はアレニウスの式に従うとした。な打，乾燥 でよく用いられる含水率 $M$ と水分濃度 $C_{\mathrm{m}}$ の関係は (13) 式で与えられる。

$$
C_{\mathrm{m}}=\rho_{\mathrm{s}} M
$$

ここで， $\rho_{\mathrm{s}}$ は固体密度 $\left(\mathrm{kg}_{\text {-solid }} / \mathrm{m}^{3}\right)$ を示す。また， 本研究試料の含水率は実験結果より, 焼成開始直後か ら焼成時間の経過に伴い数值が低下することが明らか となっている。乥こで水分移動に関する初期条件と境 界条件は以下の式に従うとした。

$$
\begin{aligned}
\text { I.C. } \mathrm{C}_{\mathrm{m}}=\mathrm{C}_{\mathrm{mi}} \\
\text { B.C. } \mathrm{C}_{\mathrm{m}}=\mathrm{C}_{\mathrm{meq}}
\end{aligned}
$$

ここで, $C_{\mathrm{mi}}$ は水分濃度の初期值, $C_{\mathrm{meq}}$ は水分濃度の 平衡值を示す.

\section{4 焼成過程における色彩値の予測}

全ての設定温度において，環境温度はオーブン庫内 の温度を一定に保つため設定温度の前後 $10^{\circ} \mathrm{C}$ の温度带 で上昇下降を繰り返していた。午のため環境温度に依 存する試料表面温度も焼成過程に打いて一定ではな かった，そこで，色彩值を算出するために必要となる 活性化エネルギー $E_{\mathrm{a}}$ と頻度因子 $Z$ を以下の手法を用い 推定した。まず，活性化エネルギーを仮定し，試料表 面温度と（10）式を用いて L* (予測值) を算出した。 
Table 1 Activation energies and pre-exponential factors at each temperature. These values were calculated using Golden section method. The temperature shows the setting temperature of the oven.

\begin{tabular}{ccc}
\hline & Eac $(\mathrm{kJ} / \mathrm{mol})$ & $\mathrm{Zc}(1 / \mathrm{s})$ \\
\hline $100^{\circ} \mathrm{C}$ & 63 & $4.80 \times 10^{5}$ \\
$120^{\circ} \mathrm{C}$ & 61 & $4.80 \times 10^{5}$ \\
$150^{\circ} \mathrm{C}$ & 61 & $5.19 \times 10^{5}$ \\
\hline
\end{tabular}

またこの際，実測值と予測值の誤差が最小になるよう な頻度因子を黄金分割法（Golden Section method）に よって求めた。この操作を複数回繰り返し，実測值と 予測した $\mathrm{L}^{*}$ の䛊差が最小となった各設定温度の活性化 エネルギーと頻度因子を Table 1 に示す．算出した色彩 值の活性化エネルギーは $61(\mathrm{~kJ} / \mathrm{mol})$ もしくは $63(\mathrm{~kJ} /$ $\mathrm{mol})$ ，頻度因子は $4.80 \pm 10^{5}(1 / \mathrm{s})$ もしくは $5.19 \times$ $10^{5}(1 / \mathrm{s})$ となり，これらの值は表面温度 $100 \sim 150^{\circ} \mathrm{C}$ において色彩值を予測した既存の報告 [15,17,20-22] と オーダーが一致していることから妥当であると判断し た.また Nakamura ら [15] はマダイを焼成し，試料表 面温度 80 〜 $180^{\circ} \mathrm{C}$ に打ける色彩変化を予測した際，速度 パラメータのひとつである活性化エネルギーは温度依 存性がないとみなし, 活性化エネルギーを平均化して いる。また色彩值の予測計算とは異なるが，Kajitani ら [23] は異なる塩分濃度で塩漬けした豚肉のタンパク質 変性度の予測を行うにあたり，活性化エネルギーは塩 分濃度に依存しないとみなし塩分濃度 2〜 $40 \mathrm{mg} / \mathrm{g}$ を平 均化している。本研究に打いても色彩值の活性化エネ ルギーは $61(\mathrm{~kJ} / \mathrm{mol})$ もしくは $63(\mathrm{~kJ} / \mathrm{mol})$ である ことから温度依存性はないとみなし, 活性化エネルギー を平均化した。そして平均化した活性化エネルギー

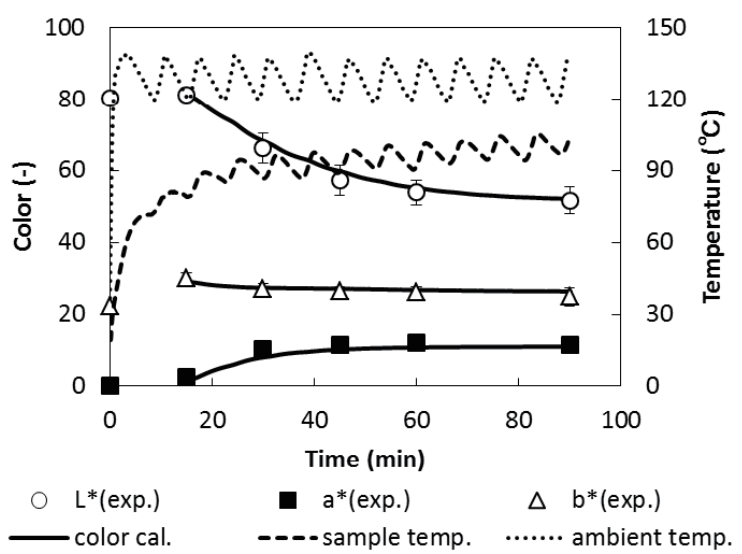

Fig.4 Comparison of calculated and measured $\mathrm{L}^{*}, \mathrm{a}^{*}$, and $\mathrm{b}^{*}$ values. Setting temperature of the oven is $120{ }^{\circ} \mathrm{C}$. It was assumed that the change of the color of the calculated value began from heating start 15 minutes. Li and Lf of the calculated value used measured value. The measured values are expressed as the mean \pm S.D. $(n=25)$
$61.6 \mathrm{~kJ} / \mathrm{mol}$ に対する各温度の頻度因子を算出した結 果， $4.80 \times 10^{5} 1 / \mathrm{s}$ もしは $5.19 \times 10^{5}(1 / \mathrm{s})$ とほぼ等 しいことから，頻度因子についても平均化を行った。

平均化した活性化エネルギー $(61.6 \mathrm{~kJ} / \mathrm{mol})$ と平均 化した頻度因子 $\left(4.93 \times 10^{5} 1 / \mathrm{s}\right)$ ，ならびに焼成時の 試料表面温度をアレニウスの式に代入し, RKG 法 (Runge-Kutta-Gill method) を用いて設定温度 $120^{\circ} \mathrm{C}$ における数值計算の結果と実測值を比較した（Fig.4）. Fig.4より，推算した $\mathrm{L}^{*}$ と，近似式である（1）式と（2） 式を用いて算出した $a^{*} と b^{*}$ は実測值を良好に再現して いることを確認した。

\section{5 含水率変化に基づく水分活性と破断応力の予測}

実験結果より含水率は焼成開始直後から焼成時間の 経過に伴い，数值が低下することが明らかとなってい る. 含水率の減少, すなわち試料中の水分の物質移動 は試料の温度に依存する。試料の伝熱現象は熱拡散率, 物質移動現象は拡散係数が支配因子となるが，おから の原料である大豆の熱拡散率は $8.268 \times 10^{-8} \sim 1.496 \times$ $10^{-7} \mathrm{~m}^{2} / \mathrm{s}$ [24], 拡散 係数は $4.595 \times 10^{-11} \sim 3.325 \times$ $10^{-10} \mathrm{~m}^{2} / \mathrm{s}$ [25] と, 熱拡散率は拡散係数の約 100 倍であ ることから，物質移動現象が律速であると考えた。さ らには，焼成前の試料厚みは $1.50 \pm 0.27 \mathrm{~mm}$ と薄いこ とから，厚み方向における不均一な温度分布は生じな いと仮定し，水分分布のみ考慮し予測計算を行った。 拡散係数を算出するための温度は実測した試料表面温 度を，活性化エネルギーと振動数因子は大豆を焼成温 度 $100 \sim 160^{\circ} \mathrm{C}$ で乾燥させた際に算出した值 $(31.4 \mathrm{~kJ} /$ mol, $3.483 \times 10^{-5} \mathrm{~m}^{2} / \mathrm{s}$ [26]）を使用し，差分近似法を 用いてフィックの法則に基づく拡散方程式を解き，含 水率変化を計算した。その結果，焼成開始直後は，試

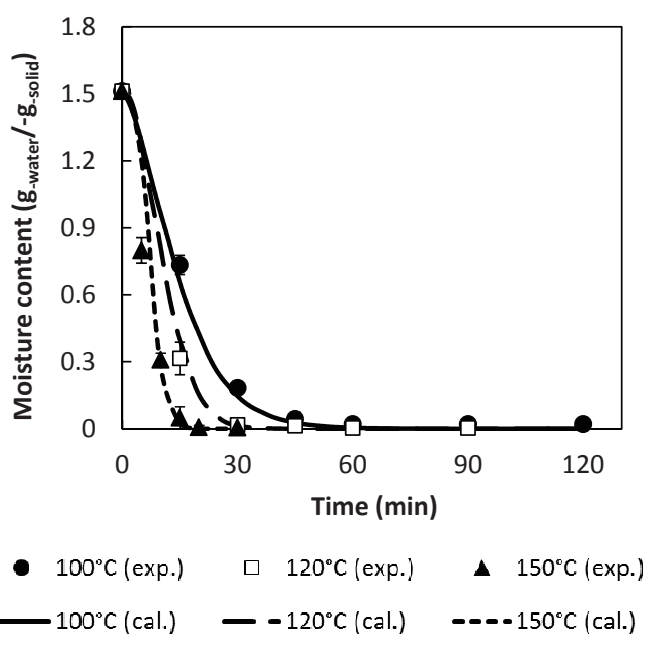

Fig.5 Comparison of calculated and measured moisture content. The temperature shows the setting temperature of the oven. The measured values are expressed as the mean \pm S.D. $(n=8)$ 
料表面の含水率と中心部の含水率は $1.49\left(\mathrm{~g}_{\text {-water }} /\right.$ $\mathrm{g}_{\text {-solid }}$ )の差が存在したが，焼成時間の経過に伴い含水 率の差は小さくなり，設定温度 $100^{\circ} \mathrm{C}$ では 60 分後，設 定温度 $120^{\circ} \mathrm{C}$ では 33 分後, 設定温度 $150^{\circ} \mathrm{C}$ では 18 分後 に，試料内部の含水率は均一になることが明らかとなっ た. Fig.5に予測した試料内部の含水率を平均化した含 水率（以後，平均含水率）と実測值の比較を示す。平 均含水率の予測值は, 試料内に不均一な含水率分布が 存在する加熱初期も含め，全ての焼成時間において実 測值と一致していることがみて取れる。そこで次に， 予測した平均含水率と水分活性 ((3) 式), 破断応力 ( (4) 式）の相関式を用いて，すべての設定温度に打ける水 分活性と破断応力の実測値と予測值を比較した。 Fig.6 に示す水分活性と破断応力の予測值は実測值の傾向を 良好に再現していることがみて取れる。したがって， 物質移動解析により算出した平均含水率と相関式を用 いることで含水率，破断応力，水分活性の 3 項目を予 測できると判断した.

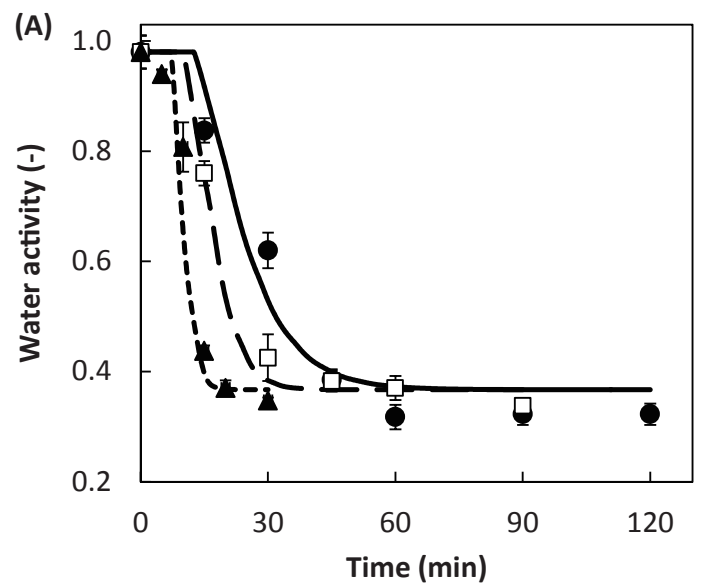

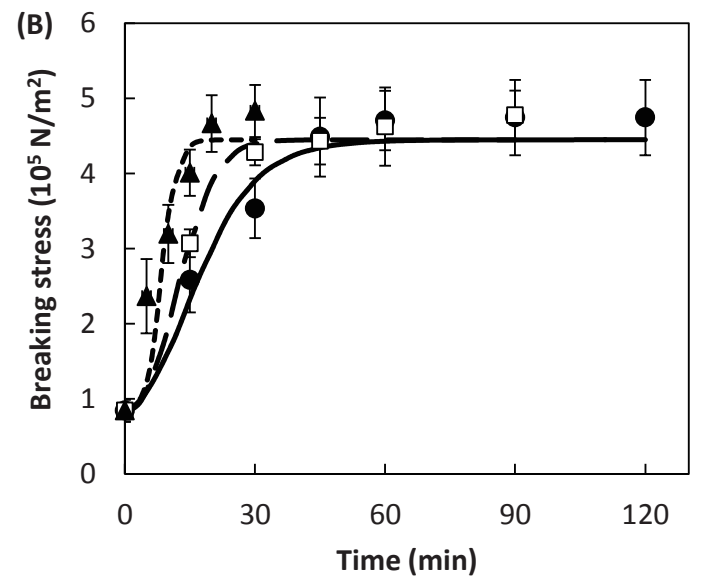

\section{6 予測計算に基づく焼成条件の検討}

予測した色彩值，含水率，水分活性打よび破断応力 は実測値と良好に一致することを確認できた。そこで 同様な手法を用いて焼成時間の経過に伴う品質変化を 予測し，市販品の品質に近い值を示す焼成条件の検討 を行った。ところで，焼成器具によって設定温度と試 料表面温度の変化は異なることが予想される。 そこで 本研究では加熱開始直後に試料表面温度は 80，90, $100 ， 110$ 扣よび $120^{\circ} \mathrm{C}$ に到達し，焼成終了時まで一定 であると仮定した。また，実験結果から試料表面温度 $80^{\circ} \mathrm{C}$ に到達後, $\mathrm{L}^{*}$ が低下し呈色が始まると明らかになっ ていることから，今回行った予測計算では全ての設定 温度において L* は焼成開始直後から緩やかに減少する と仮定した。さらには，今回予測した品質の中で水分 活性は保存性の観点から最も重要であると考え，市販 品のブランフレークの水分活性 0.37 (乾物基準含水率 $\left.0.03 \mathrm{~g}_{\text {-water }} / \mathrm{g}_{\text {-solid }}\right)$ を指標とし [7]，市販品の数値に到 達する時間を算出した。各設定温度において市販品の 水分活性に到達するまでに要した時間と，予測した色

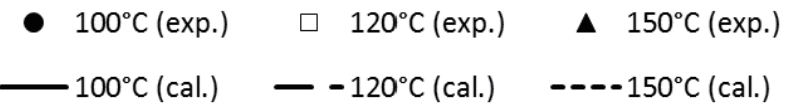

Fig.6 Comparison of calculated and measured values. (A) Water activity, (B) Breaking stress. The temperature shows the setting temperature of the oven. The measured values are expressed as the mean \pm S.D. $(n=8)$

Table 2 Predicted the heating time required for to water activity 0.37 . Comparison between measured color values of the commercial product and calculated values.

\begin{tabular}{ccccc|ccc}
\hline \multicolumn{3}{c}{ Calculated values } & \multicolumn{3}{c}{ Commercial product [7] } \\
\hline $\begin{array}{c}\text { Surface } \\
\text { temp. }\end{array}$ & time (min) & $\mathrm{L}^{*}$ & $\mathrm{a}^{*}$ & $\mathrm{~b}^{*}$ & $\mathrm{~L}^{*}$ & $\mathrm{a}^{*}$ & $\mathrm{~b}^{*}$ \\
\hline $80^{\circ} \mathrm{C}$ & 58.8 & 57.9 & 10.5 & 27.0 & & & \\
$90^{\circ} \mathrm{C}$ & 52.0 & 53.7 & 11.1 & 26.6 & 46.4 & 7.96 & \pm \\
$100^{\circ} \mathrm{C}$ & 48.3 & 51.0 & 11.1 & 26.2 & \pm & \pm .8 & 0.95 \\
$110^{\circ} \mathrm{C}$ & 46.3 & 50.1 & 11.1 & 26.0 & 1.77 & 0.36 & \pm \\
$120^{\circ} \mathrm{C}$ & 31.6 & 50.0 & 11.1 & 26.0 & & & \\
\hline
\end{tabular}


彩值，市販品のブランフレークの色彩值を Table 2 に示 す。予測計算を実施するにあたり，指標とする水分活 性を $0.37(-)$ と固定したため，含水率に基づいて計算 する破断応力の予測值は全ての設定温度において共通 の值 $\left(4.46 \times 10^{5} \mathrm{~N} / \mathrm{m}^{2}\right)$ を示した。 またTable 2 に示し た色彩值の予測值より， $\mathrm{a}^{*}$ と $\mathrm{b}^{*}$ は全ての設定温度でほ ぼ共通であり，かつ市販品の数值に近い值を示すこと が明らかとなった。これに対して $\mathrm{L}^{*}$ の予測值は設定温 度が高くなるにしたがい数值が低下したため，表面温 度を $120^{\circ} \mathrm{C}$ 一定で焼成した試料が市販品の $\mathrm{L}^{*} に$ 最も近 い值を示した。ところで本研究試料では，設定温度 $100^{\circ} \mathrm{C}$ で 90〜120 分焼成した試料の水分活性と色彩值は 市販品と同等になる [7] ことと, 設定温度 $100^{\circ} \mathrm{C}$ の表面 温度は焼成開始から約 15 分時に $80^{\circ} \mathrm{C}$ 到達以降，環境温 度に依存して上昇下降を繰り返すことが明らかとなっ ている。また，表面温度を常に $80^{\circ} \mathrm{C}$ と仮定した予測計 算では，市販品と同等の品質を担保するまでに 58.8 分 要すると提示された（Table 2)。予測計算で得られた焼 成時間が短くなった要因として，設定温度 $100^{\circ} \mathrm{C} て ゙$ 焼成 した試料は表面温度が $80^{\circ} \mathrm{C}$ に到達するまでに約 15 分要 したこと，環境温度の上昇下降に伴い，表面温度が変 動した $\left(80^{\circ} \mathrm{C} よ り\right.$ 低い温度帯になる $)$ こが挙げられる. したがって，強制対流などを利用し効率的に試料表面 温度を上昇させ，さらに環境温度が一定の焼成器具を 利用することで，焼成時間を短縮できると考えられる. また本研究試料では，表面温度を $80^{\circ} \mathrm{C}$ から $120^{\circ} \mathrm{C}$ に変 更することで，焼成時間を約 $1 / 2$ に短縮できることが 示唆された。

このようにシミュレーション手法を用いて複数の品 質を予測可能とすることで，求める品質を製造するた めの焼成時間の短縮化に貢献することができる。しか し，焼成温度によって必要となるエネルギー量は異な るため，今後は各設定温度で要するエネルギーの推算 を予測計算に設定することで，品質のみならず環境負 荷を考慮した焼成条件を探索することが可能となる. また今回は市販品の定量值を指標としたが，官能試験 を行い消費者が好む色や硬さを検証し最終值に設定す ることで，消費者の嗜好を反映した商品の開発につな がると考えられ，シミュレーション手法のさらなる発 展が期待される.

\section{4. 結}

\section{論}

本研究は，豊富な栄養価をもつにも関わらず大量に廃 棄されている生打からの有効利用を目的として作製され た加工食品を対象とし，焼成過程に打ける品質変化の予 測計算を試みた。色彩值の変化は一次反応で表すことが できると考え，速度パラメータ $\left(E_{\mathrm{a}}=61.6 \mathrm{~kJ} / \mathrm{mol}, Z=\right.$ $\left.4.93 \times 10^{5} 1 / \mathrm{s}\right)$ を算出した。含水率はフィックの法則に
基づく物質移動解析を用いて推算した. $\mathrm{L}^{*}$ と $\mathrm{a}^{*}, \mathrm{~b}^{*}$ の 相関式，含水率と水分活性，破断応力の相関式を利用し， 予測值と実測值を比較したところ，色彩值，含水率，水 分活性および破断応力の全ての項目において良好に一致 した。そこで同様な手法を用いて市販品と同等な品質を 担保するための焼成条件を検討したところ，表面温度を $80^{\circ} \mathrm{C}$ から $120^{\circ} \mathrm{C}$ に変更することで，焼成時間を約 $1 / 2$ に 短縮できることが示唆された。このようにシミュレー ション手法を用いて複数の品質を予測可能とすること で，求める品質を製造するための焼成時間の短縮化に貢 献することができる.

\section{謝辞}

本研究にご協力いただきました株式会社ライクスタ カギ，星田博文氏，稲川幹夫氏，安藤祥充氏に深く感 謝いたします。

\section{NOMENCLATURE}

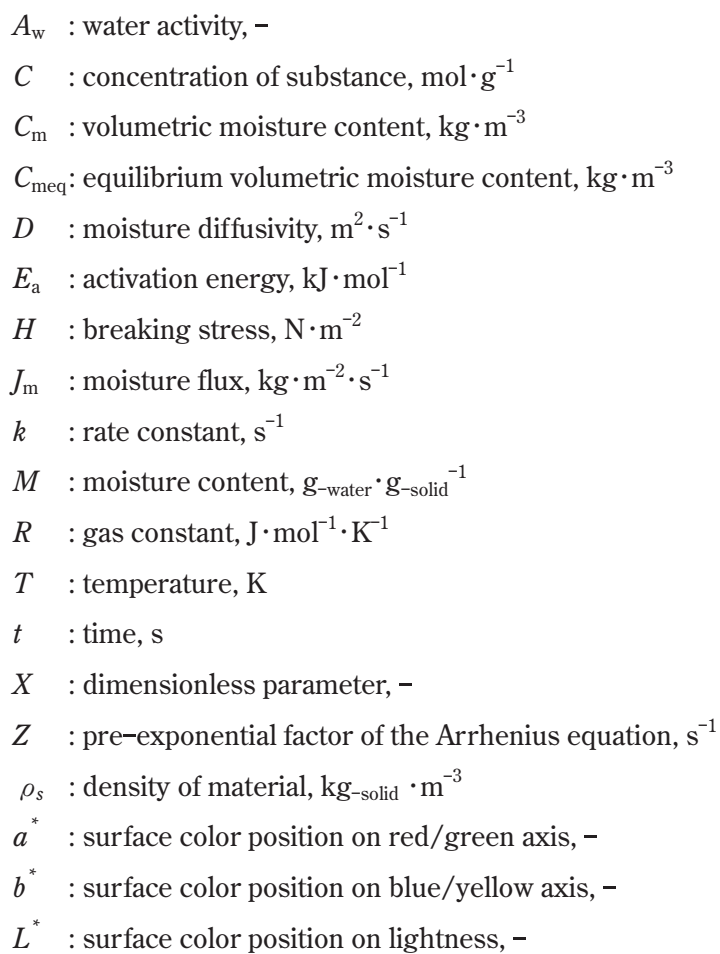

\section{Subscripts}

$f$ : final

$i$ : initial

$m:$ moisture content

\section{引用 文 献}

1) T. Tsuda, T. Haumi, T. Watanabe; "Utilization of bean-cured refuse (okara) in fiber - bread processing " (in Japanese). J. 
Cookery Sci. Jpn., 29, 25-31 (1996).

2) R. Horiuchi, Y. Sugihara, M. Fukuda; "Effect of addition of dry okara on breadmaking properties" (in Japanese), J. Integr. Stud. Diet. Habits., 14,328-338 (2004).

3) Y. Kainuma, T. Hinjyou; "Effects of roasting on the properties of raw okara and improving baked bread” (in Japanese), J. Cookery Sci. Jpn., 42, 285-293 (2009).

4) T. Kudou, H. Nagura, J. Kurisaki; "Utilization of okara in daily meals: Properties and sensory evaluation of boiled rice, bread and udon containing okara as a part of ingredients" (in Japanese), J. Integr. Stud. Diet Habits., 24, 154-161 (2013).

5) M. Matsuo; "Utilization of cooked and pasted okara-tempeh as an ingredient of pancake or croquette" (in Japanese), J. Home Econ. Jpn., 58, 41-47 (2007).

6) H. Tokieda, R. Ikeda, S. Cho; "Cooking properties, preservation stabilities and sensory acceptability of okara added bakery products" (in Japanese), Food Preservation Sci., 29, 269-274 (2003).

7) N. Shibata-Ishiwatari, M. Kawaguchi, Y. Ando, M. Inagawa, H. Hoshida; "Development of a processed food product using raw okara as the principle raw material” (in Japanese). J. Cookery Sci. Jpn., 49, 355-361 (2016).

8) N. Ishiwatari, M. Fukuoka, N. Sakai; Effect of protein denaturation degree on texture and water state of cooked meat. J. Food Eng., 117, 361-369 (2013).

9) N. Ishiwatari, M. Fukuoka, N. Hamada-Sato, N. Sakai; Decomposition kinetics umami component during meat cooking. J. Food Eng., 119, 324-331 (2013).

10) N. Ishiwatari, K. Tsutsumi, M. Fukuoka, K. Watanabe, Y. Taguchi, K. Kudou, I. Watanabe, N. Sakai; "Optimal heat sterilization of a hamburger patty during single-sided panfrying. Part2: Effect of timing the hamburger patty turning on the sterilizing value” (in Japanese). J. Cookery Sci. Jpn., 45, 275-284 (2012).

11) D. Ou, G. S. Mittal; Single- sided pan frying of frozen hamburgers with flippings for microbial safety using modeling and simulatioin. J. Food Eng., 80, 33-45 (2007).

12) Z. Pan, R. P. Shingh; Heating surface temperature and contact-heat transfer coefficient of a clam-shell grill. Lebesm. Wiss. Thechnol., 35, 348-354 (2002).

13) D. Ou, G. S. Mittal: Double-sided pan-frying of unfrozen/ frozen hamburgers for microbial safety using modeling and simulation. Food Res. Int., 39, 133-134 (2006).

14) K. L. Yam, S. E. Papadakis; A simple digital imaging method for measuring and analyzing color of food surface. J. Food Eng., 61, 137-142 (2004).

15) M. Nakamura, W. Mao, M. Fukuoka, N. Sakai; Analysis of the Color Change in Fish during the Grilling Process. Food Sci. Technol. Res., 17, 471-478 (2011).

16) M. Onishi, M. Inoue, T. Araki, H. Iwabuchi, Y. Sagara; Characteristic coloring curve for white bread during baking. Bio. Biotechnol. Biochem., 75, 255-260 (2011).

17) H. Matsuda, Y. Llave, M. Fukuoka, N. Sakai; Color changes in fish during grilling - Influences of heat transfer and heating medium on browning color. J. Food Eng., 116, 130-137 (2013).

18) X. Yu, Y. Llave, M. Fukuoka, N., Sakai; Estimation of color changes in fish surface at the beginning of grilling base on the degree of protein denaturation. J. Food Eng., 129, 12-20 (2014).

19) Y. Llave, X. Yu, M. Fukuoka, N. Sakai; Analysis of the color developed during carbonization of grilled fish by kinetics and computer imaging. Food Sci. Technol. Res., 20, 1051-1061 (2014).

20) B. Broyart, G. Trystram, A. Duquenoy; Predicting colour kinetics during craker baking. J. Food Eng., 35, 351-368 (1998).

21) J. Zhang, A. K. Datta; Mathematical modeling of bread baking process. J. Food Eng., 75, 78-89 (2006).

22) F. Kong, J. Tang, B. Rasco, C. Crapo; Kinetics of salmon quality changes during thermal processing. J. Food Eng., 83, 510-520 (2007).

23) S. Kajitani, M. Fukuoka, N. Sakai; Kinetics of thermal denaturation of protein in cured pork meat. Jpn. J. Food Engineering, 12, 19-26 (2011).

24) R. Ince, E. Guzel, A. Ince; Thermal properties of some oily seeds. J. Agr. Machinery Sci., 4. 399-405(2008).

25) S. Minasee, M. H. Khoshtaghaza, H. Darvishi;Fluidized Bed Drying Characteristics of Soybeans. J. Agr. Sci.Tech,16, 1017-1031(2014).

26) R. M. Torrez Irigoyen, S. A. Giner; Drying-toasting kinetics of presoaked soybean in fluidized bed. Experimental study and mathematical modelling with analytical solutions. J. Food Eng., 128, 31-39 (2014). 